\title{
Determinants consumers' preferences for milk in Maranhão, Brazil
}

\section{Fatores determinantes das preferências dos consumidores de leite no Maranhão, Brasil}

\author{
Francisco Martins de Castro ${ }^{1}$; Zinaldo Firmino da Silva ${ }^{2 *}$; \\ Ivan Barbosa Machado Sampaio ${ }^{3}$; Taciana Galba da Silva Tenório ${ }^{4}$
}

\begin{abstract}
In cities with different population profiles and marketing, cultural aspects can prevail in a purchase decision. The milk markets are different in the cities of Chapadinha, Imperatriz, and São Luís, Maranhão State, Brazil. To study milk consumption semi-structured questionnaires were filled among consumers in order to register their habits and preferences during the dry and rainy seasons. Socioeconomic and cultural data of the consumers and aspects referring to the milk type consumed were considered. The results from 2,134 respondents were treated using descriptive statistics and the chi-squared test. The consumption and preference for milk type differed $(\mathrm{P}<0.01)$ between the cities. Higher proportions of milk drinkers were found in Chapadinha and São Luís compared to Imperatriz. The inhabitants of Chapadinha, São Luís, and Imperatriz preferred powdered, UHT, and pasteurized milk, respectively. Powdered milk was chosen in Chapadinha due to price and convenience $(\mathrm{P}<0.001)$. The milk types in São Luís (UHT) and Imperatriz (pasteurized) were chosen to ensure the populations' health. The differences in the purchasing power of the inhabitants, dairy farming traditions, and milk types offered at each site explains the varied consumption behavior. Disclosing information to the public about the nutritional and health aspects of formal milk must take into account the regional diversity of the consumers.
\end{abstract}

Key words: Informal milk, consumer preferences, milk supply chain

\section{Resumo}

Em cidades com perfis mercadológicos e populacionais distintos, aspectos culturais podem prevalecer na decisão de compra. Com o objetivo de conhecer a proporção da população de consumidores de leite de três cidades maranhenses e seus hábitos e preferências de consumo, foram aplicados questionários semi-estruturados à população. Foram consideradas informações socioeconômicas e culturais dos consumidores e de aspectos referentes ao tipo de leite consumido. Os resultados de 2.134 respondentes foram tratados por meio de estatística descritiva e do teste de qui-quadrado. O consumo e preferência pelo tipo de leite diferiram $(P<0,01)$ entre as cidades. Em Chapadinha e São Luís identificou-se maior proporção de consumidores de leite em comparação a Imperatriz. Os habitantes de Chapadinha, São Luís e Imperatriz preferiram, respectivamente, leite em pó, longa vida e pasteurizado. A escolha pelo

${ }^{1}$ Discente, Pós-graduação em Agronomia Tropical, Universidade Federal do Amazonas, UFAM, Manaus, AM, Brasil. E-mail: fcastrozoot@hotmail.com

2 Prof., Curso de Zootecnia, Centro de Ciências Agrárias e Ambientais, Universidade Federal do Maranhão, UFMA, Chapadinha, MA, Brasil.E-mail: zf.silva@ufma.br

3 Prof., Escola de Veterinária, Universidade Federal de Minas Gerais, UFMG, Belo Horizonte, MG, Brasil. E-mail: ibms@vet. ufmg.br

${ }^{4}$ Prof $^{\mathrm{a}}$, Dept ${ }^{\mathrm{o}}$ Clínica e Cirurgia Veterinária, Universidade Federal do Piauí, UFPI, Teresina, PI, Brasil. E-mail: tacianagalba@ yahoo.com.br

* Autor para correspondência 
leite em pó em Chapadinha foi devida ao preço e conveniência ( $\mathrm{P}<0,001)$. Em São Luís (longa vida) e em Imperatriz (pasteurizado) a escolha pelo tipo de leite foi em função das garantias à saúde. As diferenças no poder aquisitivo dos habitantes, na tradição pecuária leiteira e na oferta dos tipos de leite de cada local explicam a variação no comportamento do consumo. A divulgação de informações junto à população sobre os aspectos nutricionais e de saúde do leite formal precisam se adequar a diversidade regional dos consumidores.

Palavras-chave: Cadeia produtiva do leite, leite informal, preferências de consumo

\section{Introduction}

The Brazilian Health Ministry, through its Food Guide, recommends the daily consumption of three servings of milk and / or its products (BRASIL, 2006). In Brazil, the theoretical milk availability -produced plus imports and minus exports - is 178 liters per inhabitant per year. Nevertheless, the Brazilian national mean consumption per capita of 45 and 93.5 liters of dairy product equivalents, for the lower and higher income classes, respectively, as evidenced by Zoccal (2013) in compiled data from the 2008/2009 Household Budget Survey (Pesquisa de Orçamentos Familiares) of the Brazilian Institute of Geography and Statistics (INSTITUTO BRASILEIRO DE GEOGRAFIA E ESTATÍSTICA - IBGE). The relative contribution of dairy products to the diet of Brazilian households is only $5.77 \%$, with $76.94 \%$ of this quantity in the form of liquid milk (LEVY et al., 2012).

In addition to the insufficient quantity, there is variation in the composition and quality of the milk consumed, especially raw milk, which presents a health risk (RIBEIRO NETO et al., 2012). Although illegal, the sale of raw milk in Brazil represents an important alternative trade, although informal milk consumption is decreasing annually with the progressive industrialization of milk (IBGE, 2013b).

Of the five geographic mesoregions that comprise Maranhão State, Brazil, the western mesoregion, formed by three microregions (Pindaré, Gurupi, and Imperatriz), represents $62.6 \%$ of all milk production in the state. The Imperatriz microregion alone, comprising 16 municipalities, produces half of this milk (IBGE, 2012). Additionally, 76\% of the dairy industries under state and federal inspection of the state are concentrated in the area around the municipality of Imperatriz. In contrast, municipalities such as Chapadinha (located in the eastern mesoregion) and São Luís (the state capital located in the northern mesoregion), which lack expressive milk production, differ in the diversity query and availability of commercial products. The municipality of São Luís has a higher number and diversity of retail chains containing milk and its derivatives, whereas in Chapadinha, the largest supply of milk is powdered and has a UHT. This situation is important because it represents differences in the supply of products to consumers and can influence consumption habits (ENGEL, 2000).

This study aimed to determine the proportion of consumers of milk from Maranhão population and consumer preferences in different markets in order to be identified its determinants.

\section{Material and Methods}

This study was conducted as a survey using semistructured questionnaires that were administered verbally and individually to the population in the second half of 2009 and then in the first half of 2010. The questionnaires contained multiple choice questions about personal information, education, family income and consumption behavior of milk according to the type of processing (UHT, powdered, pasteurized and in raw milk) and the reasons that led him to make choices (price, convenience, security aspects of health or taste) in each of the three cities studied. The respondents were approached at their own convenience, in public places with population flows at different times of the day, to cover a wider 
range of possible respondent types. Half of the forms were administered to men, and the other half were administered to women, since men than women participate less in voluntary surveys (COLONNA et al., 2011).

The study was conducted at two different times, considering the highest and lowest rainfall in Maranhão State, Brazil (SILVA et al., 2011), during the dry season (October, November, and December) and rainy season (March, April, and May). This schedule was selected due to the variation in milk supply, mainly raw milk, which naturally undergoes changes throughout the year due to differences in rainfall and the consequent impact on pasture production.

The sample consisted of 2,400 forms, of which 800 were distributed per city, divided equally into two seasons. The cities studied, Chapadinha, Imperatriz, and São Luís had populations of 65,000, 232,000, and 998,000 inhabitants, respectively (IBGE, 2013a). General social, economic, and cultural data and aspects related to preferences and reasons for choosing different milk types consumed in each of the three cities studied were considered.
The data obtained were analyzed using descriptive statistics to obtain the relative frequencies of the attributes of the sample studied and the variables related to the respondent profiles (sex, age, marital status, educational background, and income).

The chi-squared test was used to test the association between all variables for milk consumption and cities or seasons (dry and rainy). The milk consumption declared by the respondents was considered to be the dependent variable, and the variables related to the milk type and the reasons for the consumers' purchase choice were considered to be independent variables. Probability values of less than 0.05 indicated that the test was significant and that the variables were associated.

\section{Results and Discussion}

Questionnaire responses from 2,134 respondents were used to analyze the milk consumer profiles and consumption preferences in the three cities studied. Participation by both genders in the study was equivalent between the cities and seasons (Figure 1).

Figure 1. Gender of the milk consumers in Chapadinha ( $n=641$ ), São Luís ( $n=698)$, and Imperatriz ( $n=340)$, Maranhão State, Brazil, during the rainy and dry seasons.

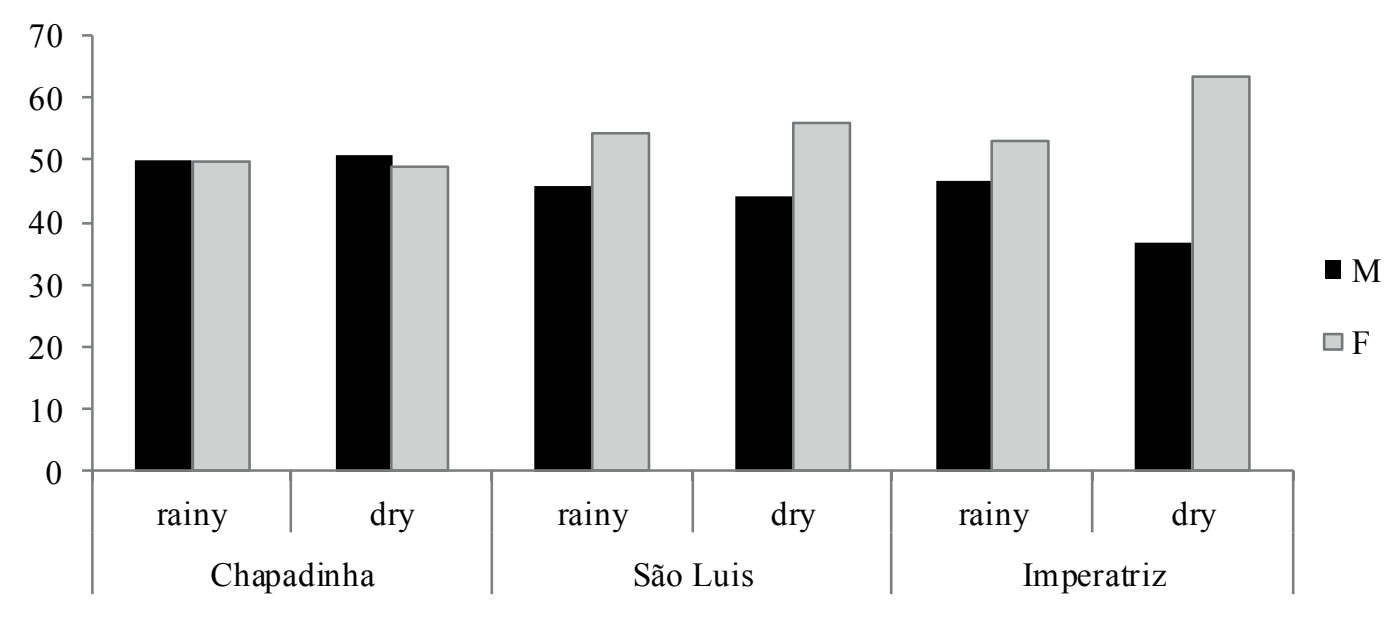


There was a different situation regarding the respondent age, in which the city of Chapadinha had a higher proportion of people who were less than 20 years of age during the rainy season (Figure 2). In general, the 21 - to 30 -year-old age range was more frequent and predominated compared with the 20- to 40-year-old age range.

Figure 2. Age range (in years) of the milk consumers in Chapadinha ( $\mathrm{n}=619)$, São Luís ( $\mathrm{n}=702)$ and Imperatriz $(\mathrm{n}=343)$, Maranhão State, Brazil during the rainy and dry seasons.

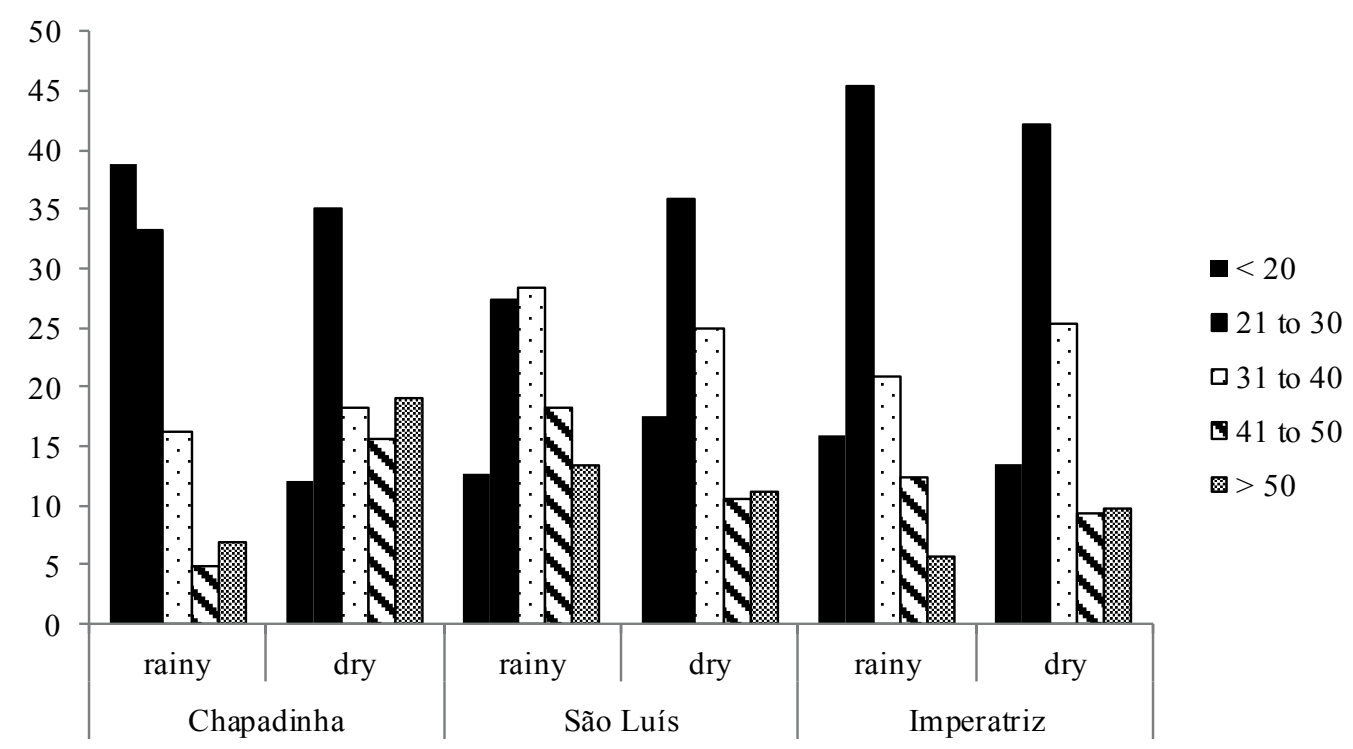

The marital status of the respondents was equivalent the seasons, except for the city of Chapadinha during the rainy season, which exhibited approximately 30\% more single individuals (Figure 3). This finding is consistent with the higher concentration of younger respondents observed (Figure 2).

Figure 3. Marital status of the milk consumers in Chapadinha ( $n=641)$, São Luís ( $n=690)$, and Imperatriz ( $n=339$ ), Maranhão State, Brazil, during the rainy and dry seasons.

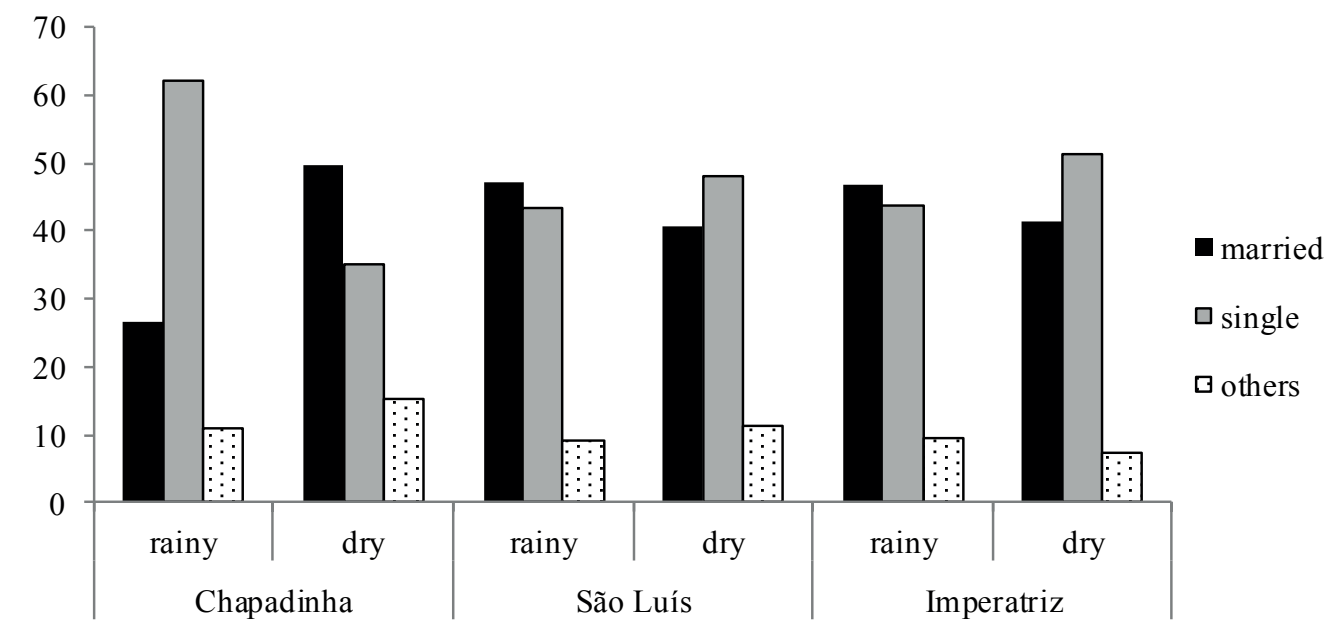


Regarding respondents' education levels, a high school-level education was predominant in all of the cities (Figure 4). Chapadinha and Imperatriz had more illiterate and fewer college-level milk consumers than São Luís. The education was equivalent between the seasons (Figure 4).

Figure 4. Education level of the milk consumers in Chapadinha ( $n=642)$, São Luís ( $n=688)$, and Imperatriz ( $n=336$ ) during the rainy and dry seasons.

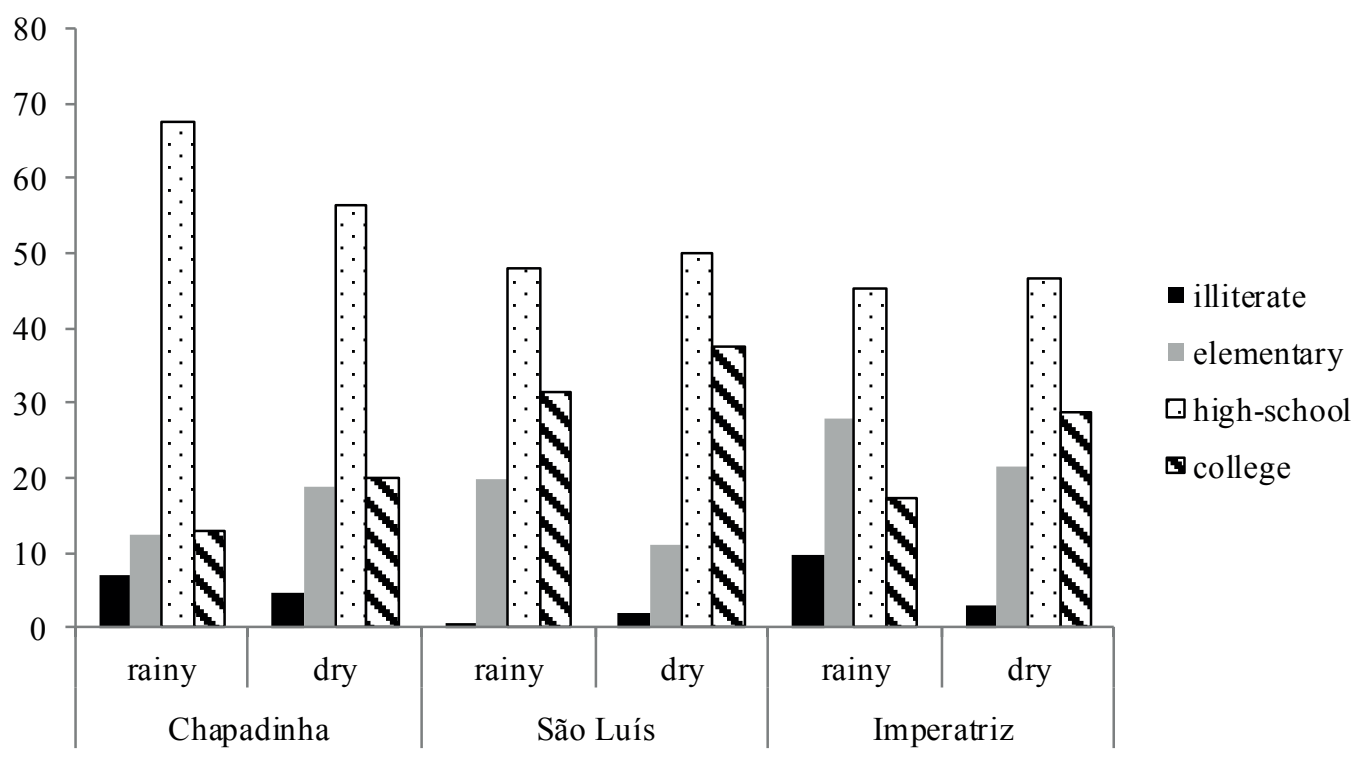

Chapadinha had a higher proportion of respondents with a family income of less than minimum wage (BR $\$ 678.00$ is equivalent to US $\$ 293.50)$, followed by those who received between one and three times the minimum wage (Figure 5). Similarly, Imperatriz had a higher proportion of people with low income, although the largest portion of the sample consisted of those who received between one and three times the minimum wage. The respondents in São Luís had higher incomes, with some of them receiving between one and three times the minimum wage, followed by those who received between three and six times the minimum wage. In summary, the income level in descending order for the respondents was those from São Luís, Imperatriz, and Chapadinha. The chi-squared test revealed that populations in Chapadinha and São Luís had higher $(\mathrm{P}<0.01)$ proportions of milk consumers compared with Imperatriz (Table 1).
In general, the proportion of milk consumers in these populations was lower than that observed in a study in Southeastern Brazil (91\%) in Janaúba-MG (AGUILAR et al., 2012). This finding is consistent with the lower relative proportion of these components in the diets of northeastern Brazilians compared with consumers from the southern and southeastern regions of Brazil (LEVY et al., 2012).

In general, the proportion of milk consumers in these populations was lower than that observed in a study in Southeastern Brazil (91\%) in Janaúba-MG (AGUILAR et al., 2012). This finding is consistent with the lower relative proportion of these components in the diets of northeastern Brazilians compared with consumers from the southern and southeastern regions of Brazil (LEVY et al., 2012).

Only the city of Chapadinha had a lower $(\mathrm{P}<0.01)$ proportion of milk consumers during the dry season compared with the rainy season, with a $10 \%$ difference (Table 2). 
Figure 5. Monthly income ranges (in minimum wages, BR \$678.00 is equivalent to US \$293.50) of the milk consumers in Chapadinha ( $\mathrm{n}=637)$, São Luís ( $\mathrm{n}=642)$, and Imperatriz $(\mathrm{n}=334)$, during the rainy and dry seasons, Maranhão State, Brazil.

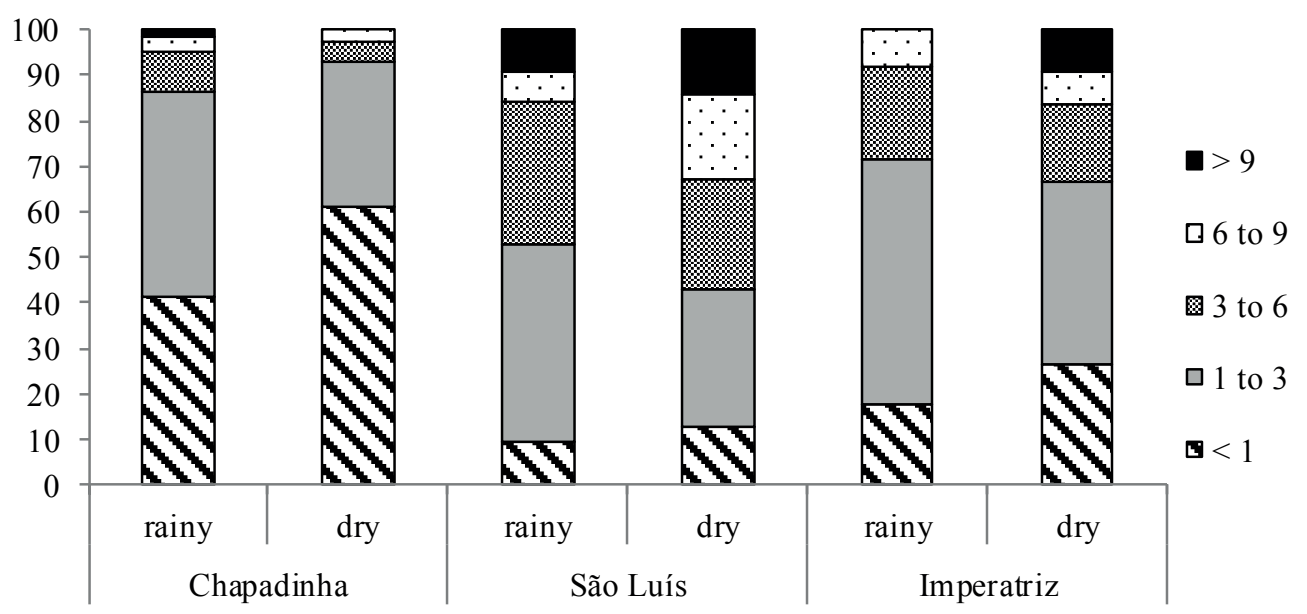

Table 1. Absolute and relative frequencies of milk consumers in the cities of Chapadinha, São Luís, and Imperatriz, Maranhão State, Brazil.

\begin{tabular}{lrl}
\hline \multicolumn{1}{c}{ Milk consumption } & \multicolumn{1}{c}{ No } & Yes \\
\hline Chapadinha & $130(17 \%)$ & $640(83 \%)$ \\
Imperatriz & $206(38 \%)$ & $340(62 \%)^{* * *}$ \\
São Luís & $92(12 \%)$ & $698(88 \%)$ \\
\hline
\end{tabular}

${ }^{* * *}$ Significant difference between the cities by the chi-squared test (df $\left.2, \mathrm{P}<0.0001\right)$.

Table 2. Relative frequency of milk consumption during the rainy and dry seasons in Chapadinha, São Luís, and Imperatriz, Maranhão State, Brazil.

\begin{tabular}{lcccc}
\hline \multirow{2}{*}{ City } & \multirow{2}{*}{ Season } & \multicolumn{2}{c}{ Milk consumption } & \multirow{2}{*}{$\mathrm{P}<$} \\
\cline { 2 - 3 } Chapadinha & Rainy & $62(15.5 \%)$ & $338(84.5 \%)$ & \multirow{2}{*}{$* *$} \\
& Dry & $98(24.5 \%)$ & $302(75.5 \%)$ & \\
São Luís & & & \\
& Rainy & $43(11 \%)$ & $357(89 \%)$ & \multirow{2}{*}{ ns } \\
& Dry & $49(13 \%)$ & $341(87 \%)$ & \\
Imperatriz & Rainy & $68(39 \%)$ & $105(61 \%)$ & \\
& Dry & $138(37 \%)$ & $235(63 \%)$ & ns \\
\hline
\end{tabular}

**Significant difference between the seasons by the chi-squared test ( df $1, \mathrm{P}<0.01$ ).

NS Not significant by the chi-squared test ( $\mathrm{df} 1, \mathrm{P}>0.05)$.

The comparison of milk consumption between the two rainy seasons was important because milk production in Maranhão State, Brazil, is exclusively pasture-dependent (SILVA et al., 2012) and this 
pasture-dependent production, in turn, is directly affected by rainfall. The rainy and dry seasons in Maranhão State, Brazil, occur during the second and fourth quarter of the year, respectively (SILVA et al., 2011).
A difference $(\mathrm{P}<0.0001)$ was observed between the cities regarding the milk type consumed (Table 3). The inhabitants of Chapadinha, São Luís, and Imperatriz preferred powdered, UHT, and pasteurized and fresh milk, respectively (Table 3).

Table 3. Milk type preferred by consumers in Chapadinha, São Luís, and Imperatriz, Maranhão State, Brazil.

\begin{tabular}{lllcc}
\hline \multirow{2}{*}{ City } & \multicolumn{4}{c}{ Milk type } \\
\cline { 2 - 4 } \multicolumn{1}{c}{ Powdered } & \multicolumn{1}{c}{ Raw } & UHT & Pasteurized \\
\hline Chapadinha & $447(70 \%)^{*}$ & $96(15 \%)$ & $68(11 \%)$ & $29(5 \%)$ \\
São Luís & $359(52 \%)$ & $59(8 \%)$ & $234(34 \%)^{*}$ & $45(6 \%)$ \\
Imperatriz & $71(21 \%)$ & $93(28 \%)^{*}$ & $56(17 \%)$ & $112(34 \%)^{*}$ \\
\hline
\end{tabular}

(*) Significant difference between the cities by the chi-squared test (df $6, \mathrm{P}<0.0001$ ).

Liquid milk (UHT, raw, and pasteurized) was more preferred than powdered milk $(\mathrm{P}<0.001)$ by the inhabitants of Imperatriz (79\%). Raw milk consumption was prevalent in Imperatriz as the second largest proportion of milk type consumed (28\%, Table 3). This finding is explained by the increased milk supply in this city, as Imperatriz is one of eight cities with the largest production in the state, unlike Chapadinha and São Luís, which have no representation in the production segment (IBGE, 2012). However, the percentage of raw milk consumers in Imperatriz was lower than the means for the cities of southeastern Brazil (35\%) (AGUILAR et al., 2012) and was close to the national mean of $31 \%$ in 2011 (IBGE, 2013b). However, raw milk consumption is not recommended due to the high variation in its microbiological quality (MATTOS et al., 2010; TEBALDI et al., 2008) and to the risk it therefore presents to consumer health. As evidenced by Ribeiro Neto et al. (2012), milk from Maranhão State had the second highest total bacterial count $(\mathrm{TBC}=1,460,000.93 \mathrm{CFU} / \mathrm{mL}$ milk) in northeastern Brazil, which could be due to flaws in the milking and milk-cooling procedures on dairy farms. This corroborates the findings of Silva et al. (2012), who showed that the practice of manual milking in an open corral, without a cemented floor and with suckling calves still with the cow is the majoritarian system in the largest dairy farms in the state of Imperatriz.

Powdered-milk consumers may consume less milk per day in liter equivalents compared with consumers who prefer fluid milk. Thus, there are reasons to believe that the differences observed in the proportion of consumers between the cities do not represent differences in the quantities consumed - as for example, in the cities of Chapadinha and Imperatriz. There was a change in consumer habits in the three cities studied regarding the milk type consumed between seasons (Table 4). 
Table 4. Milk type preferred by consumers during the rainy and dry seasons in the cities of Chapadinha, São Luís, and Imperatriz, Maranhão State, Brazil.

\begin{tabular}{|c|c|c|c|c|c|c|}
\hline \multirow{2}{*}{ City } & \multirow{2}{*}{ Season } & \multicolumn{4}{|c|}{ Milk type } & \multirow{2}{*}{$\mathrm{P}<$} \\
\hline & & Powdered & Raw & UHT & Pasteurized & \\
\hline \multirow{2}{*}{ Chapadinha } & Rainy & $215(64 \%)$ & $52(15 \%)$ & $58(\mathbf{1 7 \%})$ & $13(4 \%)$ & \multirow{2}{*}{$* * *$} \\
\hline & Dry & $232(77 \%)$ & $44(15 \%)$ & $10(3 \%)$ & $16(5 \%)$ & \\
\hline \multirow{2}{*}{ São Luís } & Rainy & $203(57 \%)$ & $19(5 \%)$ & $113(32 \%)$ & $21(6 \%)$ & \multirow{2}{*}{$* *$} \\
\hline & Dry & $156(46 \%)$ & $40(12 \%)$ & $121(35 \%)$ & $24(7 \%)$ & \\
\hline \multirow{2}{*}{ Imperatriz } & Rainy & $13(13 \%)$ & $10(10 \%)$ & $13(13 \%)$ & $66(65 \%)$ & \multirow{2}{*}{$* * *$} \\
\hline & Dry & $58(25 \%)$ & $83(36 \%)$ & $43(19 \%)$ & $46(20 \%)$ & \\
\hline
\end{tabular}

${ }^{(* *)}$ Significant difference between the cities by the chi-squared test (df $\left.3, \mathrm{P}<0.01\right)$

$(* * *)$ Significant difference between the cities by the chi-squared test (df $3, \mathrm{P}<0.001$ ).

Powdered milk was chosen more $(\mathrm{P}<0.001)$ during the dry season in Chapadinha, which was most likely due to the combination of a lower raw milk supply and a higher price per liter - due to lower production - which in turn would be associated with lower purchasing power by the population (Figure 5).

There was a decreased demand for powdered milk and an increased demand for UHT milk $(\mathrm{P}<0.01)$ in São Luís. In contrast, the population's demand for pasteurized milk decreased $(\mathrm{P}<0.001)$ in Imperatriz during the dry season, but the demand for raw milk increased $(\mathrm{P}<0.001)$. According to the Brazilian Association of UHT Milk (ASSOCIAÇÃO BRASILEIRA DE LEITE
LONGA VIDA, 2012), the demand for powdered milk is increasing due to the low raw-material supply for liquid-milk processing in northern and northeastern Brazil.

The reasons for choosing the milk types per city were also tested (Table 5), considering the milk type preference already declared. Thus, powdered milk was chosen in Chapadinha due to its price and convenience $(\mathrm{P}<0.001)$. In São Luís, UHT milk was chosen due to its convenience and health guarantee, and in Imperatriz, pasteurized milk was chosen for ensuring health. The aspect of health guarantee has been increasingly valued among the various options that determine the choice of milk (BARRETO et al., 2012).

Table 5. Absolute (relative) frequencies of the main factors influencing the decision to purchase different milk types in the cities of Chapadinha, São Luís, and Imperatriz, Maranhão State, Brazil.

Continua ...

\begin{tabular}{lccccc}
\hline \multirow{2}{*}{ Milk type } & \multicolumn{5}{c}{ Selection attributes } \\
\cline { 2 - 4 } & Flavor & Health & Price & Convenience & \\
\hline Powdered & $195(44 \%)$ & $89(20 \%)$ & $\mathbf{8 9}(\mathbf{2 0} \%)$ & $\mathbf{7 2 ( 1 6 \% )}$ & \\
Raw & $57(59 \%)$ & $34(35 \%)$ & $2(2 \%)$ & $3(3 \%)$ & $* * *$ \\
UHT & $44(65 \%)$ & $15(22 \%)$ & $0(0 \%)$ & $9(13 \%)$ & \\
Pasteurized & $9(31 \%)$ & $15(52 \%)$ & $2(7 \%)$ & $3(10 \%)$ & \\
\hline
\end{tabular}


Continuação

\begin{tabular}{|c|c|c|c|c|c|}
\hline \multicolumn{6}{|c|}{ São Luís } \\
\hline Powdered & $170(47 \%)$ & $51(14 \%)$ & $35(10 \%)$ & $102(28 \%)$ & \multirow{4}{*}{$* * *$} \\
\hline Raw & $22(37 \%)$ & $23(39 \%)$ & $6(10 \%)$ & $8(14 \%)$ & \\
\hline UHT & $79(34 \%)$ & $59(25 \%)$ & $14(6 \%)$ & $80(34 \%)$ & \\
\hline Pasteurized & $7(16 \%)$ & $13(29 \%)$ & $12(27 \%)$ & $13(29 \%)$ & \\
\hline \multicolumn{6}{|c|}{ Imperatriz } \\
\hline Powdered & $35(49 \%)$ & $9(13 \%)$ & $8(11 \%)$ & $19(27 \%)$ & \multirow{4}{*}{$* * *$} \\
\hline Raw & $32(34 \%)$ & $19(20 \%)$ & $28(30 \%)$ & $14(15 \%)$ & \\
\hline UHT & $7(13 \%)$ & $38(69 \%)$ & $1(2 \%)$ & $9(16 \%)$ & \\
\hline Pasteurized & $24(22 \%)$ & $58(52 \%)$ & $22(20 \%)$ & $7(6 \%)$ & \\
\hline
\end{tabular}

*** Significant difference between the cities by the chi-squared test (df $9, \mathrm{P}<0.0001$ ).

Income, prices, individual preferences and beliefs, cultural traditions, and geographic, environmental, social, and economic factors have been considered as interconnected and complex factors for creating food consumption patterns (GEROSA; SKOET, 2009). A higher powdered milk supply in Chapadinha, combined with a lower purchasing power (Figure 5) of the families, led to their preference, as did the consideration of the geographical location, which is close to Piauí State, Brazil. Zoccal (2013), compiling data from the 2008/2009 Household Budget Survey (Pesquisa de Orçamentos Familiares) of the IBGE, showed that Piauí State is the largest powdered milk consumer in Brazil (2.6 kg per capita per year).

In Imperatriz, the region's ranching tradition influenced the people's preference for liquid milk, including a high proportion of raw milk consumers. The existence of this type of product on the market, regardless of the reasons for its choice, maintains its habitual consumption. By contrast, the population with a high education level (Figure 2) demanded pasteurized or UHT milk. Finally, in the state capital, São Luís, the selection of UHT and powdered milks well represents the reality of the dynamics of the city's population because the products are more easily found and used in their homes, considering that there is a pasteurized milk supply in the market.

\section{Conclusions}

The cities of Chapadinha and São Luís have higher proportion of milk consumers of Imperatriz, although this does not represent differences in volume consumed. The inhabitants of Chapadinha prefer milk powder, Imperatriz of pasteurized milk and São Luís prefer the UHT and powdered milk. Moreover, Imperatriz has a higher proportion of raw milk consumers. The inhabitants of Chapadinha prefer powdered milk, those in Imperatriz prefer the liquid form (with a prevalence of pasteurized milk), and those in São Luís prefer UHT milk (followed by powdered milk).

Differences in the purchasing power of the inhabitants, in the dairy farming tradition of the regions, and in the supply of the milk types available on the market affect consumer behavior.

\section{Acknowledgements}

To the FAPEMA for providing a scientific initiation scholarship.

\section{References}

ASSOCIAÇÃO BRASILEIRA DO LEITE LONGA VIDA - ABLV. Informações gerais: mercado do leite longa vida. São Paulo: ABLV, 2012. Disponível em: $<$ http://www.ablv.org.br/fixedcontent.aspx?area $=$ setinf>. Acesso em: 2 fev. 2013. 
AGUILAR, P. B.; SILVA, F. V.; ZEFERINO, E. S.; SOARES, F. D. S.; GONÇALVES, W. C.; OLIVEIRA, F. M.; FROTA, B. C. B. Perfil dos consumidores de leites pasteurizado tipo C e esterilizado (UHT) de Janaúba MG. Semina: Ciências Agrárias, Londrina, v. 33, n. 4, p. 1581-1588, 2012.

BARRETO, M. L. J.; RANGEL, A. H. N.; MARQUES JÚNIOR, S.; OLIVEIRA, J. P.; BRITO, A. S. Fatores que influenciam na decisão de compra de leite de consumidores na cidade de Natal. Revista Caatinga, Mossoró, v. 25, n. 3, p. 118-124, 2012.

BRASIL. Ministério da Saúde. Departamento de Atenção Básica. Secretaria de Assistência à Saúde. Guia alimentar para a população brasileira: promovendo a alimentação saudável. Brasília: Ministério da Saúde, 2006. (Série A. Normas e Manuais Técnicos).

COLONNA, A.; DURHAM, C.; MEUNIER-GODDIK, L. Factors affecting consumers' preferences for and purchasing decisions regarding pasteurized and raw milk specialty cheeses. Journal of Dairy Science, Madison, v. 94, n. 10, p. 5217-5226, 2011.

ENGEL, J. F. Comportamento do consumidor. 8. ed. Rio de Janeiro: LTC, 2000.

GEROSA, S.; SKOET, J. The state of food and agriculture 2009: livestock in the balance. Rome: FAO, 2009. Available at: <http://www.fao.org/docrep/012/ i0680e/ i0680e.pdf $>$. Accessed at: 16 jan. 2013.

INSTITUTO BRASILEIRO DE GEOGRAFIA E ESTATÍSTICA - IBGE. Atlas do censo demográfico 2010. Rio de Janeiro: IBGE, 2013a. Disponível em: $<$ http://biblioteca.ibge.gov.br/index.php/bibliotecacatalogo? view $=$ detalhes $\&$ id $=264529>$. Acesso em: 16 jan. 2013.

Produção da pecuária municipal. Rio de Janeiro: IBGE, 2012. Disponível em: <ftp://ftp.ibge. gov.br/Producao_Pecuaria/Producao_da_Pecuaria_ Municipal/2012/ppm2012.pdf>. Acesso em: 16 jan. 2013.

.Pesquisa trimestral do leite. Rio de Janeiro: IBGE, 2013b. Disponível em: <http://www.sidra.ibge.gov.br/ bda/acervo/acervo9. asp $\mathrm{e}=\mathrm{c} \& \mathrm{p}=\mathrm{LT} \& \mathrm{z}=\& \mathrm{o}=>$ Acesso em: 18 jan. 2013.
LEVY, R. B.; CLARO, R. M.; MONDINI, L.; SICHIERI, R.; MONTEIRO, C. A. Regional and socioeconomic distribution of household food availability in Brazil, in 2008-2009. Revista de Saúde Pública, São Paulo, v. 46, n. 1, p. 1-9, 2012.

MATTOS, M. R.; BELOTI, V.; TAMANINI, R.; MAGNANI, D. F.; NERO, L. A.; BARROS, M. A. F.; PIRES, E. M. F.; PAQUEREAU, B. P. D. Qualidade do leite cru produzido na região do agreste de Pernambuco, Brasil. Semina: Ciências Agrárias, Londrina, v. 31, n. 1, p. 173-182, 2010.

RIBEIRO NETO, A. C.; BARBOSA, S. B. P.; JATOBÁ, R. B.; SILVA, A. M.; SILVA, C. X.; SILVA, M. J. A; SANTORO, K. R. Qualidade do leite cru refrigerado sob inspeção federal na região Nordeste. Arquivo Brasileiro de Medicina Veterinária e Zootecnia, Belo Horizonte, v. 64, n. 5, p. 1343-1351, 2012.

SILVA, V. P. R.; SILVA, V. P. R.; PEREIRA, E. E. E.; AZEVEDO, P. V.; SOUSA, F. A. S.; SOUSA, I. F. Análise da pluviometria e dias chuvosos na região Nordeste do Brasil. Revista Brasileira de Engenharia Agrícola e Ambiental, Campina Grande, v. 15, n. 2, p. 131-138, 2011.

SILVA, Z. F.; ANDRADE, A. C.; BENTO JUNIOR, F. A.; SOUSA, R. S.; LOIOLA, J. M. L. Características do sistema de produção de leite da Microrregião de Imperatriz, no Estado do Maranhão. Revista de Ciências Agrárias, Belém, v. 55, n. 2, p. 92-97, 2012.

TEBALDI, V. M. R.; OLIVEIRA, T. L. C.; BOARI, C. A.; ROBERTA HILSDORF PICCOLI, R. H. Isolamento de coliformes, estafilococos e enterococos de leite cru provenientes de tanques de refrigeração por expansão comunitários: identificação, ação lipolítica e proteolítica. Ciência e Tecnologia de Alimentos, Campinas, v. 28, n. 3, p. 753-760, 2008.

ZOCCAL, R. O consumo de leite e derivados no Brasil. Panorama do Leite. Juiz de Fora: Embrapa Gado de Leite. Ano 6, n. 74, jan. 2013. Disponível em: <http:// www.cnpgl.embrapa.br/totem/conteudo/Panorama leite/2013_01_PanoramaLeite.pdf $>$. Acesso em: 18 fev. 2013. 